\title{
Understory vegetation in natural and plantation forest ecosystem of Sarguja (C.G.), India
}

\author{
M. K. Jhariya* and D. K. Yadav \\ Department of Farm Forestry, Sarguja University, Ambikapur-497001 (C.G.), INDIA \\ *Corresponding author. E-mail: manu9589@gmail.com \\ Received: May 19, 2015; Revised received: February 11, 2016; Accepted: April 26, 2016
}

\begin{abstract}
Understory vegetation serves a special role in maintaining the structure and function of forest ecosystem as they strongly influence regeneration, seedling establishment, growth, nutrient cycling and thus the dynamics of the whole forest ecosystem. The present investigation is aimed to study the composition, structure and diversity of understory vegetation in natural forests and teak plantation of Sarguja forest division of Chhattisgarh. A total of 23 species comprising 5 shrubs and 18 herbs were recorded in natural forest while in teak plantation 3 shrub and 20 herb species were found. In natural forest a total of 4500 shrubs/ha and 8,32,000 herbs/ha were recorded while in plantation site it was 5500 shrubs/ha and 6,96,000 herbs/ha, respectively. In shrub layer the value of species diversity was 1.10 for teak plantation and 2.20 for natural forest. Simpson index was 0.23 for natural forest and 0.57 for teak plantation. The Margalef's index of richness varied from $0.23-0.48$, least in plantation site and peak in natural forest, Equitability index varied from 1.00 to 1.37, lowest in plantation site and higher in plantation site and $\beta$ diversity was 1.20 in natural forest and 2.00 in plantation site. In case of herb layer the value of Shannon index, species richness and equitability values were higher in teak plantation while the Simpsons index and beta diversity were found more in natural forest.
\end{abstract}

Keywords: Composition, Diversity, Herb, Structure, Shrub, Understory

\section{INTRODUCTION}

The ground flora forms a substantial structural component of forest ecosystem and harbors majority of diversity in deciduous forests (Gilliam and Roberts, 2003). Tropical forests are one of the richest, diverse and complex terrestrial ecosystem supporting a variety of life forms and also recognized as most used and threatened ecosystems, especially in India (Shankar, 2001). Anthropogenic disturbances in forests followed by livestock grazing adversely affect the composition of understory vegetation (Jhariya et al., 2012 and 2013). Increased human activities in the forested areas have not only led to depletion of forests but also degrade the quality of the stand (Jhariya, 2014; Jhariya et al., 2014; Pawar et al., 2014a \& b).

Understory species in tropical forests respond positively to increased light availability. Ground vegetation might prove to be a key indicator of succession status of forest. Disturbances also have profound effect on the regeneration of non-pioneer understory vegetation (Kwit and Platt, 2003). Herbaceous community varied by disturbance regimes. Disturbances at low severity usually cause little damage to overstorey but affects to understory vegetation directly (Jhariya et al., 2012). Herbaceous layer is essential component for increasing diversity of the region as well as it plays a substantial role in the process of nutrient cycling. Understory composition is often correlated with micro-climate and site conditions and provides important indications of site quality, overstory regeneration patterns and ecosystem health (Small, 2001; Jhariya and Oraon, 2012a, b, c; Pawar et al., 2012; Kittur et al., 2014a, b; Oraon et al., 2014 and 2015). Shrub layer, an components of tropical forest have important role on the diversity, structure and dynamics of tropical forest ecosystem. Limited work has been done in relation to shrubs in the tropics. But presently more emphasis has been given due to their function and importance.

Anthropogenic disturbances are more frequent in tropical deciduous forests of Chhattisgarh. These factors are causing great loss to biodiversity of the region and ultimately destructing the natural vegetation and habitat of the area. The natural forest and plantation ecosystem varied greatly in terms of strucuture, function and vegetation dynamics. Many studies (Sahu et al., 2013a, b; Sinha et al., 2014 and 2015; Yadav et al., 2015) dealing with the floristic and ecological features of the overstory have been carried out, however, the study on understory vegetation have neither yet been studied or little research work has been done in this area. Understanding the structure and diversity of understory vegetation is necessary to identify their roles and characteristics in a stand and also for the conservation and restoration of degraded environment. Therefore, in the present study an attempt has been made to 
synthesize information related to understory vegetation composition, structure and diversity pattern in natural and plantation forest ecosystem of Sarguja foest division of Chhattisgarh.

\section{MATERIALS AND METHODS}

The present work is carried out to examine the structure, composition and diversity pattern of understory vegetation in natural forest of Chendra and teak plantation (Established in the year 1962) of Sumerpur (Chendra, range Dhaurpur, 230. $3^{\prime} 14.7^{\prime}$, to $23^{\circ} 05^{\prime} 16.8^{\prime \prime}$ north latitude and $83^{\circ} 16^{\prime} 29.6^{\prime \prime}$ to $83^{\circ} 16^{\prime} 31.8^{\prime}$ 'east longitude, Beat No. 2589, Ganjhadand, Coupe No. VII and area about 47 ha ) of Sarguja forest division. Sarguja district is located in the northern part of Chhattisgarh State of India. This district has over extension between south-eastern parts of Vindhyachal-Baghelkhand region of peninsular India. It lies between $23^{\circ} 37^{\prime} 25^{\prime}$ ' to $24^{\circ} 6^{\prime} 17^{\prime}$ ' north latitude and $81^{\circ} 31^{\prime} 40^{\prime \prime}$ to $84^{\circ} 4^{\prime} 40^{\prime}$ ' 'east longitude.

The district Sarguja, is represented by very rich vegetation and biological diversity (Sinha et al., 2014 and 2015). About $58 \%$ of the area in the district lies under forests. The flora of Nazzul and other areas are changing frequently with the human activities and land-use. The physiographic division of the regions are: highlands, uplands and central plain. The climate of district is characterized by hot summer and well distributed rainfall during the monsoon season. Soil of Sarguja district can be broadly classified in four major classes: Red and Yellow Soils, Alluvial Soils, Laterite Soils and Medium blue Soils, respectively.

The stratified random sampling was laid out to analyze the understory vegetation for its composition, structure and diversity in natural and plantation forest ecosystem. The shrub layer was analyzed by randomly laying quadrats of $2 \times 2 \mathrm{~m}$. The girth at collar height of all the individual in each quadrat was measured and recorded separately. In each of these quadrat, a sub-quadrat of $50 \times 50 \mathrm{~cm}$ were randomly laid for measuring herbs. Vegetational data was quantitatively analysed for frequency, density and abundance (Curtis and McIntosh, 1950). Diversity parameters for shrub and herb layers were determined using the Shannon-Weaver information function (Shannon and Weaver, 1963). Concentration of dominance was measured following Simpson's index method (Simpson, 1949). Vegetations were also measured for species richness (Margalef, 1958), equitability (Pielou, 1966) and Beta diversity (Whittaker, 1972).

\section{RESULTS AND DISCUSSION}

Compostion and structure of understory vegetation: In the natural forest, a total of 4500 individual ha ${ }^{-1}$ comprising 5 species with 5 families were recorded for shrub layer (Table 1). The highest density (1500 shrub ha ${ }^{-1}$ ), frequency (60) and IVI (87.36) values were recorded for $C$. spinarum, whereas the peak value of basal area covered by $V$. calyculata $(2.18$ $\left.\mathrm{m}^{2} \mathrm{ha}^{-1}\right)$. The density, basal area and IVI values of individual species varied from 500-1500 shrub ha-1, 0.23$2.18 \mathrm{~m}^{2} \mathrm{ha}^{-1}$ and 26.46-87.36, respectively. While in the teak plantation a total of 3 species comprising 3 families were recorded. In plantation site higher density of shrub was found then the natural forest. The highest density (4000 shrubs ha ${ }^{-1}$ ), frequency (100), basal area $\left(2.140 \mathrm{~m}^{2} \mathrm{ha}^{-1}\right)$ and IVI (208.47) values were recorded for $L$. camara, whereas it was minimum for $V$. calyculata. The abundance to frequency ratio indicated that in natural forest $C$. spinarum only distributed regularly while the other remaining species were distributed randomly and contagiously over the area, whereas in plantation site L. camara distributed regularly while remaining species contagiously (Table 1 ).

Under the herb layer a total of 8,32,000 individual ha- ${ }^{-1}$ representing 18 species with 12 families were recorded in natural forest while in teak plantation a total of $6,96,000$ individual ha ${ }^{-1}$ comprising 20 species with 10 families were observed. The density of individual species varied from 8,000-1,76,000 individual ha ${ }^{-1}$ in natural forest, being least for A. paniculata and T. macrodonta while peak for $C$. rotundus, respectively. In the plantation site, the density of individual species ranged from 8,000-1,20,000 herb $\mathrm{ha}^{-1}$, being lowest for A. indica, C. compressus, D. aegyptium, D. triflorum, $D$. sanguinalis and $S$. cordifolia whereas highest for $O$. burmannii, respectively (Table 2). The IVI value of individual species varied from 5.57-54.72 in natural forest and 6.20-37.15 for plantation site. In natural forest all recorded species were distributed randomly and contagiously whereas regular distribution is absent. Similarly in teak plantation $D$. pulchellum and $R$. dentatus distributed regularly while the remaining species showed random and contagious distribution

Table 1. Composition of shrub layer in Sarguja forest division.

\begin{tabular}{lcccccccccc}
\hline \multirow{2}{*}{ Species } & \multicolumn{4}{c}{ Natural Forest } & \multicolumn{4}{c}{ Teak Plantation } \\
\cline { 2 - 13 } & F & D & BA & IVI & A/F & F & D & BA & IVI & A/F \\
\hline Butea superba Roxb & -- & -- & - & -- & -- & 20 & 1000 & 0.945 & 60.88 & 0.10 \\
Carissa spinarum DC. & 60 & 1500 & 1.12 & 87.36 & 0.017 & -- & - & -- & -- & -- \\
Lantana camara Linn. & 40 & 1000 & 0.34 & 50.64 & 0.025 & 100 & 4000 & 2.140 & 208.47 & 0.02 \\
Ventilago calyculata Tul. & 20 & 500 & 2.18 & 62.36 & 0.050 & 20 & 500 & 0.242 & 30.65 & 0.05 \\
Woodfordia floribunda Salist. & 20 & 500 & 0.23 & 26.46 & 0.050 & -- & -- & -- & -- & - \\
Ziziphus xylopyra Willd. & 40 & 1000 & 1.56 & 73.18 & 0.025 & -- & -- & - & -- & -- \\
Total & & 4500 & 5.43 & 300.00 & & & 5500 & 3.327 & 300.00 & \\
\hline
\end{tabular}

$\mathrm{D}=$ Density (individuals $\mathrm{ha}^{-1}$ ), $\mathrm{BA}=$ Basal area $\mathrm{m}^{2} \mathrm{ha}^{-1}, \mathrm{~A} / \mathrm{F}=$ Abundance to Frequency ratio, $\mathrm{IVI}=$ Importance Value Index 
Table 2. Composition of herb layer in Sarguja forest division.

\begin{tabular}{|c|c|c|c|c|c|c|c|c|}
\hline \multirow{2}{*}{ Species } & \multicolumn{4}{|c|}{ Natural Forest } & \multicolumn{4}{|c|}{ Teak Plantation } \\
\hline & $\mathbf{F}$ & $\mathbf{D}$ & IVI & $\mathbf{A} / \mathbf{F}$ & $\mathbf{F}$ & $\overline{\mathbf{D}}$ & IVI & $\mathbf{A} / \mathbf{F}$ \\
\hline Achyranthes aspera $\mathrm{L}$. & 60 & 56000 & 19.63 & 0.04 & 60 & 40000 & 17.34 & 0.03 \\
\hline Acmella paniculata (Wall. ex DC.) R.K.Jansen & 20 & 24000 & 10.25 & 0.15 & 40 & 48000 & 19.66 & 0.08 \\
\hline Alternanthera sessilis (L.) R.Br. ex Roem. \& Schultz & 20 & 120000 & 38.34 & 0.75 & -- & -- & -- & -- \\
\hline Andrographis paniculata Burm. f. & 20 & 8000 & 5.57 & 0.05 & -- & -- & -- & -- \\
\hline Anisomeles indica (L.) Kuntze & - & -- & - & -- & 20 & 8000 & 6.20 & 0.05 \\
\hline Aysicarpus vaginalis (L.) DC. & 40 & 48000 & 16.36 & 0.08 & 40 & 24000 & 12.21 & 0.04 \\
\hline Curculigo orchioides Gaertn. & 60 & 56000 & 19.63 & 0.04 & -- & -- & -- & - \\
\hline Cynodon dactylon $\mathrm{L}$. & 60 & 40000 & 16.78 & 0.03 & - & -- & -- & -- \\
\hline Cyperus compressus Linn. & - & - & -- & -- & 20 & 8000 & 6.20 & 0.05 \\
\hline Cyperus rotundus Linn. & 20 & 176000 & 54.72 & 1.10 & 40 & 32000 & 14.70 & 0.05 \\
\hline Dectyloctenium aegyptium (L.) Willd. & - & -- & - & -- & 20 & 8000 & 6.20 & 0.05 \\
\hline Desmodium pulchellum DC. & 40 & 16000 & 9.75 & 0.03 & 100 & 56000 & 23.69 & 0.01 \\
\hline Desmodium triflorum (L.) DC. & -- & -- & - & -- & 20 & 8000 & 6.20 & 0.05 \\
\hline Digitaria sanguinalis (L.) Scop. & -- & -- & -- & -- & 20 & 8000 & 6.20 & 0.05 \\
\hline Eragrostis amabilis (L.) Wight \& Arn. & 20 & 16000 & 7.91 & 0.10 & 20 & 16000 & 10.02 & 0.10 \\
\hline Eragrostis diarrhena (Schult. \& Schult.f.) Steud. & 20 & 24000 & 10.25 & 0.15 & 40 & 64000 & 24.63 & 0.10 \\
\hline Erysimum hieraciifolium L. f. & 20 & 24000 & 10.25 & 0.15 & -- & -- & -- & -- \\
\hline Evolvulus alsinoides (L.) & 40 & 24000 & 11.41 & 0.04 & 40 & 48000 & 19.66 & 0.08 \\
\hline Malvastrum coromandelianum (L.) Garcke & -- & - & - & -- & 60 & 48000 & 19.38 & 0.03 \\
\hline Oplismenus burmannii (Retz.) P.Beauv & 40 & 24000 & 11.41 & 0.04 & 100 & 120000 & 37.15 & 0.03 \\
\hline Paspalum conjugatum P.J.Bergius & -- & -- & -- & -- & 40 & 24000 & 12.21 & 0.04 \\
\hline Phyllanthus niruri L. & 40 & 40000 & 14.71 & 0.06 & 20 & 16000 & 10.02 & 0.10 \\
\hline Psoralea corylifolia Linn. & - & -- & - & -- & 20 & 16000 & 10.02 & 0.10 \\
\hline Rumex dentatus L. & 60 & 112000 & 29.58 & 0.08 & 100 & 96000 & 32.10 & 0.02 \\
\hline Sida cordifolia Linn. & -- & -- & -- & -- & 20 & 8000 & 6.20 & 0.05 \\
\hline Tectaria macrodonta & 20 & 8000 & 5.57 & 0.05 & - & -- & -- & -- \\
\hline Vigna pilosa Willd. & 20 & 16000 & 7.91 & 0.10 & -- & -- & -- & -- \\
\hline Total & 620 & 832000 & 300 & & 840 & 696000 & 300.0 & \\
\hline
\end{tabular}

$\mathrm{D}=$ Density (individuals $\mathrm{ha}^{-1}$ ), $\mathrm{F}=$ Frequency, $\mathrm{A} / \mathrm{F}=$ Abundance to Frequency ratio, IVI= Importance Value Index

pattern (Table 2).

Family wise distribution of herb species in natural forest revealed that most frequent families were found in the order of Poaceae (4 species of $22.22 \%$ ) $>$ Fabaceae (3 species of $16.67 \%$ ) > Amaranthaceae (2 species of $11.11 \%)>$ Acanthaceae, Asteraceae, Brassicaceae, Convolvulaceae, Cyperaceae, Euphorbiaceae, Hypoxidaceae, Polygonaceae, Tectariaceae (each 1 species of $5.57 \%$ ), respectively. While in plantation site it follow the order, Poaceae (6 species of $30.00 \%)>$ Fabaceae (4 species of $20.00 \%$ ) > Cyperaceae, Malvaceae (each 2 species of $10.00 \%)>$ Amaranthaceae, Asteraceae, Convolvulaceae, Euphorbiaceae, Lamiaceae, Polygonaceae (each 1 species of $5.00 \%$ ).

Diversity indices: Diversity indices provide the information on species richness, distribution and rate of change in species composition. Both structure and diversity of vegetation have strong functional role in controlling ecosystem process. Table 3 summarized the diversity pattern of the understory species found in both the sites. In natural forest Shannon index value and Species richness value for shurb layer was twice then the plantation site, while contrary to this Simpsons index value was twice in teak plantation then natural forest. The value of equitibility was found higher in natural forest while beta diversity was more in plantation site under the shrub layer (Table 3). In case of herb layer the value of Shannon index, species richness and equitability values were higher in teak plantation while the Simpsons index and beta diversity were found more in natural forest, respectively.

The species established in understory of natural forest and plantation sites were quite different in terms of composition, structure and diversity. The community of an ecosystem is regulated by various natural or biotic factors/forces which ultimately influence the overall structure of the community, resulting in variations of the population dynamics. Vegetational structure inventory entail the composition, stratification and community types, while diversity provides key information on species richness, distribution and rate of change in species composition. The concept of diversity is commonly considered as an important attribute of an organized community (Hairston et al., 1964). Both structure and diversity of vegetation have an important functional role in the regulation of ecosystem process. Shrubs can affect the growth of desired species, through competition for sharing of resources, or by delaying regeneration of trees following disturbance. The density of shrubs was found higher in the plantation site and least in natural forest. The reason of higher shurbs occurance in plantation site may be due to the open canopy which gives opportunities for regeneration and growth of shrubs species. Various factors are responsible for variation in understrory vegetation, including overstory composition and struc- 
Table 3. Species diversity of understory vegetation in Sarguja forest division.

\begin{tabular}{lcccc}
\hline \multirow{2}{*}{ Diversity Index } & \multicolumn{2}{c}{ Shrub Layer } & \multicolumn{2}{c}{ Herb Layer } \\
\cline { 2 - 5 } & Natural Forest & Teak Plantation & Natural Forest & Teak Plantation \\
\hline Shannon index (H) & 2.20 & 1.10 & 3.64 & 3.83 \\
Simpsons index (Cd) & 0.23 & 0.57 & 0.11 & 0.10 \\
Species richness (d) & 0.48 & 0.23 & 1.25 & 1.41 \\
Equitability (e) & 1.37 & 1.00 & 1.26 & 1.28 \\
Beta diversity ( $\beta \mathrm{d})$ & 1.20 & 2.00 & 1.50 & 1.35 \\
\hline
\end{tabular}

ture (Sangar et al., 2008; Hart and Chen, 2008), soil moisture and nutrient dynamics (Siebert, 2002; Ramadhanil et al., 2008), succession history (LaFrankie et al., 2006), management strategies (Hart and Chen, 2008), and fragmentation (Rasingam and Parthasarathy, 2009). Similar findings were also reported by Gianoli et al. (2010), Schnitzer et al. (2012) and Jhariya et al. (2012). Similarly, Mishra et al. (2008) also reported the maximum number of shrubs in the buffer area of biosphere reserve having the most anthropogenic disturbance (Sahu et al., 2008). Jhariya et al. (2012) reported that shrub species ranged between 6-10 and density varied from 1120-2480 individual/ha with the basal area of $0.59-1.11 \mathrm{~m}^{2} \mathrm{ha}^{-1}$ during pre-fire season while during the post-fire shrub species varied from 12-15 with the density of 19203360 individual/ha and basal area of $0.11-0.23 \mathrm{~m}^{2} \mathrm{ha}^{-1}$, respectively. Gerwing and Vidal (2002) have reported 2500 individuals/ha for liana and shrubs species for Amazonia forest.

Canopy openness is one of the vital indicators for herbaceous species richness and composition in an ecosystem (Roberts, 2004). The degree of removal of upper canopy lessens competition of the herb layer vegetation with this higher strata, but may result in higher competition with the shrub layer or within the herb layer itself (Roberts, 2004). The herb increases immediately after the disturbance due to general reduction in tree cover that eventually supportive to growth and development of herbaceous vegetation due to availability of resources (Jhariya et al. 2012 and 2013; Kittur et al., 2014a; Oraon et al., 2014). In the present study the total herb density varied from 696000832000 individuals $\mathrm{ha}^{-1}$. These figures are closer and/ or well within the range of herb density measured by Jhariya et al. (2012, i.e., 112000 to 668000 individuals $\mathrm{ha}^{-1}$ during pre-fire season whereas, 230000 to 510000 after fire season) and Jhariya et al. (2013, i.e., 502000 to 724000 individuals $\mathrm{ha}^{-1}$ ). Oraon et al. (2014) reported a total of 33-39 herb species in Bhoramdeo wildlife sanctuary, Kawardha (C.G.). The total density of herbs across the circle varied from 67800-146900 individuals $\mathrm{ha}^{-1}$. Sinha et al. (2015) reported the total 27 herbaceous species comprising 15 families with the total density of 776000 herbs ha $^{-1}$ which are comparable with the present estimated values.

In the present findings the $\mathrm{A} / \mathrm{F}$ ratio revealed that most of recorded species followed contiguous and random distribution pattern while regular distribution was found virtually insignificant in natrual forest and plan- tation sites of the study area. Odum (1971) explained that the most common distribution in nature is contagious due to small but significant variation in environmental conditions whereas random distribution was found under similar environmental conditions. Shadangi and Nath (2005) also reported that maximum species followed contagious distribution in the site. In line agreement with the present statements various studies also reported that the distribution of the species in a stand or sites followed contagiously and random distribution pattern while the regular distribution pattern was found almost negligible or insignificant (Oraon et al., 2014; Kittur et al., 2014a; Jhariya, 2014; Jhariya et al., 2012 \& 2013; Sinha et al., 2015).

Diversity of an area is related to variety of factors. Jhariya and Oraon (2012c) reported that the diversity indices for shrub layer varied greatly. The Shannon index varied from 2.35-3.13, equitability 1.28-1.37, species richness $0.71-1.17$, concentration of dominance $0.12-0.22$ and beta diversity $1.10-1.83$ during pre-fire season. Whereas during post-fire season it was 3.34-3.69 (Shannon index), 1.29-1.40 (equitability), 1.45-1.72 (species richness), 0.083-0.114 (Simposon's index) and 1.33-1.66 (Beta diversity), respectively. Sinha et al. (2015) reported that the Shannon index (H') of herbaceous species was 4.606, Simpson index (Cd) was 0.045, species richness (d) was 1.917 and equitability (e) was 1.397, respectively for plantation site of Sarguja (C.G.). Oraon et al. (2014) reported the diversity indices of natural forest which showed that Shannon index value for herb layer in different forest circle along the disturbance gradient varied from 2.50 4.25 , concentration of dominance $0.06-0.37$, species richness $1.35-2.19$, equitability $0.76-1.34$ and beta diversity 1.44-2.44. Jhariya and Oraon (2012b) reported the diversity parameters of herbaceous species which showed that the value of Shannon index in different sites ranged from 1.69-3.39, equitability 0.921.33, species richness $0.33-1.48$, concentration of dominance $0.11-0.37$ and beta diversity 1.50-3.80 of the herb layer in Bhoramdeo wildlife sanctuary, Kawardha (C.G.). Jhariya et al. (2013) reported that the Shannon index values ranged from 2.66-3.17, Simpson's index ranged from 0.14-0.23, species richness from $0.67-1.06$, equitability from $1.09-1.33$ and beta diversity from 2.40-3.60 for different sites of Rowghat (C.G.). Kittur et al. (2014a) measured the diversity parameters of herb layer and reported the Shannon index in different sites varied from 2.21-2.57, equitability from 1.02-1.24, species richness from 0.34 
-0.67 , concentration of dominance from $0.21-0.31$ and beta diversity from 1.81-3.33 which are closer to the present study.

\section{Conclusion}

We observed important differences in the character, composition and diversity of understory vegetation between the natural forest and plantation sites. In a nutshell, this study has demonstrated that the understory could contribute a lot to the total species richness of forests. All these results suggest that the understory vegetation should be given important consideration for the assessment of biodiversity patterns in tropical forests. Understory vegetation is important strata from the floral and founal diversity point of view which ultimately increase the biodiversity of the region. However, due to various pressure, stability of these regions is slowly decreasing. Understory vegetation is considered good for natural forest but in the plantation site it compete with the economic species and cause deletorius effect on growth, increment and ultimately on the production of stand/site. The improvement and conservation of understory cover is possible through systematic monitoring of livestock grazing and disturbance in these areas.

\section{REFERENCES}

Curtis, J.T. and McIntosh, R.P. (1950). The interrelation of certain analysis and systematic phytosociological characters. Ecology, 31: 434-455.

Gerwing, J.J. and Vidal, E. (2002). Changes in liana abundance and species diversity eight years after liana cutting and logging in an Amazonia forest. Conservation Biology, 16: 544-548.

Gianoli, E., Saldana, A., Jimenez-Castillo, M. and Valladares, F. (2010). Distribution and abundance of vines along the light gradient in southern temperate rain forest. Journal of Vegetation Science, 21: 66-73.

Gilliam, F.S. and Roberts, M.R. (2003). Conceptual framework for studies of the herbaceous layer. In: Gilliam FS, Roberts MR (eds) The herbaceous layer in forests of Eastern North America. Oxford University Press, Oxford, pp 3-11.

Hairston, N.G., Smith, F.E. and Slobodkin, L.D. (1964). Community structure, population control and competition. American Naturalist, 94.

Hart, S.A. and Chen, H.Y.H. (2008). Fire, logging, and overstory affect understory abundance, diversity, and composition in boreal forest. Ecol.Monogr., 78: 123-140.

Jhariya, M.K. (2014). Effect of forest fire on microbial biomass, storage and sequestration of carbon in a tropical deciduous forest of Chhattisgarh. Ph.D. Thesis, I.G.K.V., Raipur (C.G.), pp. 259.

Jhariya, M.K., Bargali, S.S., Swamy, S.L., Kittur, B., Bargali, K. and Pawar, G.V. (2014). Impact of forest fire on biomass and carbon storage pattern of tropical deciduous forests in Bhoramdeo wildlife sanctuary, Chhattisgarh. International Journal of Ecology and Environmental Sciences, 40(1): 57-74.

Jhariya, M.K., Bargali, S.S., Swamy, S.L. and Oraon, P.R. (2013). Herbaceous diversity in proposed mining area of Rowghat in Narayanpur District of Chhattisgarh, India.
Journal of Plant Development Sciences, 5(4): 385-393. Jhariya, M.K., Bargali, S.S., Swamy, S.L. and Kittur, B. (2012). Vegetational Structure, Diversity and Fuel Load in Fire Affected Areas of Tropical Dry Deciduous Forests in Chhattisgarh. Vegetos, 25(1): 210-224.

Jhariya, M.K. and Oraon, P.R. (2012a). Regeneration Status and Species Diversity along the Fire Gradients in Tropical Deciduous Forest of Chhattisgarh. Journal of Plant Development Sciences, 4(1): 49-54.

Jhariya, M.K. and Oraon, P.R. (2012b). Analysis of herbaceous diversity in fire affected areas of Bhoramdeo Wildlife Sanctuary, Chhattisgarh. The Bioscan, 7(2): 325-330.

Jhariya, M.K. and Oraon, P.R. (2012c). Lianas and Shrubs Regeneration, Distribution Pattern and Diversity in Tropical Forest Ecosystem of Chhattisgarh. The Bioscan, 7(3): 377-382.

Kittur, B., Swamy, S.L., Bargali, S.S. and Jhariya, M.K. (2014a). Wildland Fires and Moist Deciduous Forests of Chhattisgarh, India: Divergent Component Assessment. Journal of Forestry Research, 25(4): 857-866 (DOI) 10.1007/s11676-014-0471-0.

Kittur, B., Jhariya, M.K. and Lal, C. (2014b). Is the forest fire can affect the regeneration and species diversity. Ecology, Environment and Conservation, 20(3): 989994.

Kwit, C. and Platt, W.J. (2003). Disturbance history influences regeneration of non-pioneer under storey trees. Ecology, 84(10): 2575-2578.

LaFrankie, J.V., Ashton, P.S., Chuyong, G.B., Condit, L. Co, R., Davies, S.J., Foster, R., Hubbell, S.P., Kenfack, D., Lagunzad, D., Losos, E.C., Nor, N.S.M., Tan, S., Thomas, D.W., Valencia, R. and Villa, G. (2006). Contrasting structure and composition of the understory in species-rich tropical rain forests. Ecology, 87: 2298-2305.

Margalef, R. (1958). Perspective in ecological theory. University of Chicago Press, Chicago.

Mishra, R.K., Upadhyay, V.P. and Mohanty, R.C. (2008). Vegetation Ecology of the Simplipal Biosphere Reserve, Orissa India. Applied Ecology and Environment Research, 6(2): 89-99.

Odum, E.P. (1971). Fundamental of Ecology. Saunders Co., Philadelphia.

Oraon, P.R., Singh, L. and Jhariya, M.K. (2014). Variations in Herbaceous Composition of Dry Tropics Following Anthropogenic Disturbed Environment. Current World Environment, 9(3): 967-979.

Oraon, P.R., Singh, L. and Jhariya, M.K. (2015). Shrub Species Diversity in Relation to Anthropogenic Disturbance of Bhoramdeo Wildlife Sanctuary, Chhattisgarh. Environment and Ecology, 33(2A): 996-1002.

Pawar, G.V., Singh, L., Jhariya, M.K. and Sahu, K.P. (2014a.). Effect of Anthropogenic Disturbances on Biomass and Carbon Storage Potential of a Dry Tropical Forest in India. Journal of Applied and Natural Science, 6(2): 383-392.

Pawar, G.V., Singh, L., Jhariya, M.K. and Sahu, K.P. (2014b). Assessment of Diversity along the Disturbance Gradient in Dry Tropics of Chhattisgarh, India. The Ecoscan, 8(3\&4): 225-233.

Pawar, G.V., Singh, L., Jhariya, M.K. and Sahu, K.P. (2012). Regeneration status in relation to anthropogenic disturbance in tropical deciduous forest of Chhattisgarh. The Ecoscan, (Special Issue) 1: 281-285.

Pielou, E.C. (1966). Species diversity and pattern diversity in 
the study of ecological succession. J. Theor. Biol., 10: 370-383.

Ramadhanil, R., Tjitrosoedirdjo, S.S. and Setiadi, D. (2008). Structure and composition of understory plant assemblages of six land use types in the Lore Lindau National Park, Central Sulawesi, Indonesia. Bangladesh Journal of Plant Taxonomy, 15: 1-12.

Rasingam, L. and Parthasarathy, N. (2009). Diversity of understory plants in undisturbed and disturbed tropical lowland forests of Little Andaman Island, India. Biodivers. Conserv., 18: 1045-1065.

Roberts, M.R. (2004). Response of the herbaceous layer to natural disturbance in North American forests. Can $J$ Bot, 82: 1273-1283.

Sahu, K.P., Singh, L., Alone, R.A., Jhariya, M.K. and Pawar, G.V. (2013a). Biomass and Carbon Storage Pattern in an Age Series of Teak Plantation in Dry Tropics. Vegetos, 26(1): 205-217.

Sahu, K.P., Singh, L. and Jhariya, M.K. (2013b). Fine root biomass, forest floor and nutrient status of soil in an age series of teak plantation in dry tropics. The Bioscan, 8 (4): 1149-1152.

Sahu, P.K., Sagar, R. and Singh, J.S. (2008). Tropical forest structure and diversity in relation to altitude and disturbance in a Biosphere Reserve in central India. Applied Vegetation Science, 11: 461-470.

Sangar, R., Singh, A. and Singh, J.S. (2008). Differential effect of woody plant canopies on species composition and diversity of ground vegetation: a case study. Trop. Ecol., 49: 189-197.

Schnitzer, S.A., Bongers, F. and Powers, J. (2012). Understanding the increase in lianas in neotropical forests. In: Symposium (12) "Ecology, Evolution and Sustainable use of Tropical Biodiversity", 18-22 June, 2012. Bonito Convention Center, Brazil.
Shadangi, D.K. and Nath, V. (2005). Impact of seasons on ground flora under plantation and natural forest in Amarkantak. Ind. For., 131(2): 240-250.

Shankar, U. (2001). A case of high tree diversity in a Sal (Shorea robusta) dominated lowland forest of eastern Himalaya: Floristic composition, regeneration and conservation. Current Science, 81(7): 776-786.

Shannon, C.E. and Weaver, W. (1963). The Mathematical Theory of Communication. Urbana, USA: University of Illinois Press.

Siebert, S. (2002). From shade to sun-grown perennial crops in Sulawesi, Indonesia: implications for biodiversity conservation and soil fertility. Biodiversity and Conservation, 11: 1889-1902.

Simpson, E.H. (1949). Measurement of diversity. Nature, 163: 688.

Sinha, R., Jhariya, M.K. and Yadav, D.K. (2015). Assessment of Sal Seedlings and Herbaceous Flora in the Khairbar Plantation of Sarguja Forest Division, Chhattisgarh. Current World Environment, 10(1): 330-337.

Sinha, R., Yadav, D.K. and Jhariya, M.K. (2014). Growth performance of Sal in Mahamaya central forest nursery (Ambikapur), Chhattisgarh. International Journal of Scientific Research, 3(11): 246-248.

Small, C.J. (2001). Environmental and Plant Biology Herb Layer Dynamics and Disturbance Response in the Mixed Mesophytic Forest Region of Southeastern Ohio. Ph.D. Thesis (176pp.).

Whittaker, R.H. (1972). Evolution and measurement of species diversity. Taxon, 21:213-251 .

Yadav, D.K., Jhariya, M.K., Kumar, A. and Sinha, R. (2015). Documentation and Ethnobotanical importance of Medicinal Plants found in Sarguja district. Journal of Plant Development Sciences, 7(5): 439-446. 